\title{
The conversion of plant nitrogen to microbial nitrogen in the rumen of the sheep
}

\author{
By R. A. WELLER, F. V. GRAY AND A. F. PILGRIM \\ Division of Biochemistry and General Nutrition of the Commonwealth Scientific \\ and Industrial Research Organization, University of Adelaide, South Australia
}

(Received 22 April 1958)

An estimate of the extent of conversion of plant nitrogen to microbial nitrogen in the rumen of sheep fed on wheaten hay was reported in an earlier communication (Gray \& Pilgrim, 1953). The basis of separation of plant from microbial material was simply the filtration of the rumen contents through muslin with subsequent limited washing of the fibrous plant residues to free them from the remaining bacteria. This procedure must have involved two main sources of error-contamination of the washed fibres with bacteria, and contamination of the filtrate and washings with very fine plant particles, but no attempt was made at that time to assess the magnitude of these errors. It was known that considerable amounts of nitrogen could be removed from the fibres by further washings, but at the same time it was realized that the physical separation of plant and microbial elements was not necessarily being improved, since further quantities of fine plant particles were also being washed into the filtrate.

Later a chemical basis was adopted for assessment of the contamination of the washed fibres by bacteria, and $a, \epsilon$-diaminopimelic acid was selected for this purpose since it is present in the bacteria of the rumen in sheep, but not in the protozoa or in the plant substances of the fodder. Because it is absent from the protozoa it was hoped to use it also as a basis for the separation of bacterial and protozoal nitrogen. Since it was possible that the bacteria contaminating the washed fibres might have a different composition from the rest of the bacteria, it was considered desirable to check the suitability of the amino-acid as a marker of bacterial protein by comparing it in this respect with some other, quite separate substance present in bacteria but not in plants. For this purpose vitamin $B_{12}$ was selected.

The present experiments extend the findings previously reported and show that diaminopimelic acid can be used as a marker of bacterial nitrogen to reduce a major source of error in the former calculations. An attempt was also made to correct for the second source of error-the contamination of the microbial fractions by fine plant particles. It is not possible, of course, to know the precise error remaining, but there can be no doubt that these extensions to the procedure have improved the original estimates of the extent of conversion of plant nitrogen to microbial nitrogen in the rumen. 


\section{EXPERIMENTAL}

The Merino sheep used in the experiments were all fed on chaffed wheaten hay and received a weekly drench containing $10 \mathrm{mg}$ cobalt as cobalt chloride. They were maintained on this diet for at least 2 weeks before being slaughtered. Three sheep were used for a study of the distribution of diaminopimelic acid and vitamin $B_{12}$ in relation to the nitrogen in various fractions of the rumen contents. Six other sheep were used for a further study similar to that reported earlier (Gray \& Pilgrim, 1953).

\section{Experiment I}

Three sheep which had been fed on a daily ration of 800-1000 $\mathrm{g}$ wheaten hay were slaughtered at $4, \mathrm{I} 6$ and $24 \mathrm{~h}$ after the beginning of feeding, and the contents of the reticulo-rumen sac were collected immediately. In order to obtain representative samples of the very heterogeneous contents the whole was first squeezed through muslin. Suitable portions of the moist solids and filtrate so formed were recombined to provide the necessary smaller samples of the original material.

Samples of rumen contents weighing $200-300 \mathrm{~g}$ were subjected to two separate treatments:

(a) The rumen material was first separated into two fractions, 'washed fibres' and 'washings', by squeezing through muslin and washing the coarse plant residues twice with volumes of water equal to the original volume of rumen fluid. Then a portion of the washings was passed through a Seitz filter to give a bacteria-free filtrate.

Analyses carried out on these three fractions included the determination of lignin $(\mathrm{L})$, nitrogen $(\mathrm{N})$, diaminopimelic-acid nitrogen (DAP-N), and vitamin $\mathrm{B}_{12}$ activity in the washed fibres; N, DAP-N and vitamin $B_{12}$ in the washings; and $N$ alone in the Seitz filtrate.

(b) In a second sample of the rumen contents the solids were precipitated by ethanol as described by Gray, Pilgrim \& Weller (1958a) and the lignin present in these solids was determined.

The remainder of the rumen fluid (left over after the reconstruction of the samples) was used for the preparation of large samples of the rumen bacteria and the rumen protozoa. The protozoa and plant debris were first separated off by gentle centrifuging and the bacteria in the supernatant liquid were collected in a Sharples supercentrifuge, as described by Weller (1957). The protozoa were washed several times until examination showed that they were virtually free from plant particles and bacteria. $\mathrm{N}, \mathrm{DAP}-\mathrm{N}$ and vitamin $\mathrm{B}_{12}$ were determined in the preparations of bacteria, and $\mathrm{N}$ and DAP-N in the protozoa.

\section{Experiment 2}

Six sheep which had been fed on a constant daily ration of $800 \mathrm{~g}$ wheaten hay were slaughtered at $2,5,7$, I0, 16 and $24 \mathrm{~h}$, respectively, after the beginning of feeding. These sheep were at the same time being used in experiments already reported by Gray et al. (1958a), and some of the results overlap both inquiries. Samples of the 
rumen contents were obtained as in Exp. I. They were subjected to the same treatments and analytical procedures, but no preparations of the rumen bacteria were made.

\section{Determination of nitrogen and lignin}

Nitrogen was determined by the Kjeldhal method. Lignin was determined by the $72 \% \mathrm{H}_{2} \mathrm{SO}_{2}$ method (see Gray et al. $\mathrm{I} 958 \mathrm{a}$ ).

\section{Determination of diaminopimelic acid}

\section{Preparation of samples for hydrolysis}

Washed fibres. Samples containing about $\mathrm{I} \cdot 5 \mathrm{~g}$ of the dried ground material were used without further treatment.

Washings. Volumes chosen to contain about $50 \mathrm{mg}$ total nitrogen were mixed with three volumes of ethanol. The precipitated solids were separated by centrifuging, washed with ethanol and ether, and dried.

Bacteria. Samples of the separated bacteria suspended in water and containing about $70 \mathrm{mg}$ total nitrogen were adjusted to $\mathrm{pH}_{4} .5$ with acetic acid. Three volumes of ethanol were added and the precipitated solids were separated, washed with ethanol and ether, and dried.

\section{Hydrolysis}

The samples were hydrolysed by refluxing for $22 \mathrm{~h}$ with $100 \mathrm{ml}$. twice-distilled constant-boiling $\mathrm{HCl}$. The hydrolysates were cooled, filtered and washed through no. 42 Whatman paper, and the filtrates concentrated at $35^{\circ}$ to $\mathrm{I} \mathrm{ml}$. in a rotary evaporator. After dilution to a suitable volume $2 \mathrm{ml}$. portions containing about $0.02 \mathrm{mg}$ DAP-N were dried in vacuo for use on the chromatographic column.

\section{Chromatography}

Separation of diaminopimelic acid (DAP) was effected on a $100 \mathrm{~cm}$ column of $8 \%$ cross-linked Dowex 50 resin (The Dow Chemical Co., Delaware, California) by a modification of the Moore \& Stein (I95I) technique. Elution was carried out at $37.5^{\circ}$ with $0.1 \mathrm{M}$ citrate buffer at $\mathrm{pH}_{3} .68$ throughout. Under these conditions DAP emerged from the column after about I 20 ( $\mathrm{I} \mathrm{ml}$.) fractions, following valine and preceding methionine, the relative position of the DAP peak between these amino-acids being sensitive to changes in the $\mathrm{pH}$ of the eluting buffer. With the particular resin used, buffer at $\mathrm{pH}_{3} .68$ gave complete separation of DAP from adjacent peaks, even when the column was heavily overloaded with other amino-acids.

\section{Diaminopimelic-acid nitrogen}

DAP-N in the fractions was determined by the photometric ninhydrin method of Moore \& Stein (1948) with diaminopimelic-acid standards.

\section{Determination of vitamin $B_{12}$}

Extracts for the determination of vitamin $B_{12}$ activity by tube assay with Lactobacillus leichmannii 3 × 3 were made from the samples of rumen bacteria and washed fibres as described by Dawbarn \& Hine (1954) and Hine \& Dawbarn (1954). For one 
sheep the vitamin $\mathrm{B}_{12}$ activity was also assayed with Ochromonas malhamensis and the calculated values for extent of bacterial contamination in washed fibres were essentially the same as those determined by Lb. leichmannii assay.

\section{RESULTS}

The concentrations of DAP-N and vitamin $B_{12}$ in relation to the bacterial nitrogen from the sheep in Exp. I are given in Table $I$, together with the concentrations of these substances in the washed-fibre fractions of the nitrogen. From these values the extent of contamination of the washed fibres is readily calculated, and the last two columns of Table I show the results, based on $(a)$ the DAP-N concentrations, and $(b)$ the vita$\min B_{12}$ concentrations.

Table 1. Exp. I. Bacterial contamination of washed fibres from rumen contents of sheep

\begin{tabular}{|c|c|c|c|c|c|c|c|}
\hline \multirow{3}{*}{$\begin{array}{l}\text { Time after } \\
\text { beginning } \\
\text { of } \\
\text { feeding } \\
\text { (h) }\end{array}$} & \multicolumn{2}{|c|}{ Rumen bacteria } & \multirow{2}{*}{\multicolumn{3}{|c|}{$\begin{array}{l}\text { Washed fibres from } 100 \mathrm{~g} \\
\text { rumen contents }\end{array}$}} & \multicolumn{2}{|c|}{ to bacterial-N } \\
\hline & & Vitamin & & & & Calculated & Calculated \\
\hline & $\begin{array}{c}\text { DAP-N } \\
(\mathrm{mg} / \mathrm{g} \\
\text { total } \mathrm{N})\end{array}$ & $\begin{array}{c}\mathrm{B}_{12}^{*} \\
(\mu \mathrm{g} / \mathrm{g} \\
\text { total } \mathrm{N})\end{array}$ & $\begin{array}{l}\text { Total N } \\
\text { (mg) }\end{array}$ & $\begin{array}{l}\text { DAP-N } \\
(\mathrm{mg})\end{array}$ & $\begin{array}{c}\text { Vitamin } \\
\mathrm{B}_{12} \\
(\mu \mathrm{g})\end{array}$ & $\begin{array}{c}\text { from } \\
\text { DAP-N } \\
\text { content }\end{array}$ & $\begin{array}{c}\text { from } \\
\text { vitamin } B_{12} \\
\text { content }\end{array}$ \\
\hline 4 & $5 \cdot 74$ & $25 \cdot 0$ & $84 \cdot 5$ & 0.194 & 0.70 & 40 & 33 \\
\hline 16 & $6 \cdot 55$ & $132 \cdot 0$ & $76 \cdot 6$ & 0.249 & & 50 & 41 \\
\hline 24 & $6 \cdot 40$ & $153^{\circ} 0$ & $57 \cdot 7$ & 0.155 & $2 \cdot 8$ & 42 & 32 \\
\hline
\end{tabular}

* In sheep fed on wheaten hay the vitamin $B_{12}$ content of the bacteria varied widely according to the time which elapsed between the last cobalt drench and the time of sampling.

Table 2. Exp. 2. Distribution of nitrogen between crude fractions of rumen contents of six sheep

$\begin{array}{cccc}\begin{array}{c}\text { Time after } \\ \text { beginning } \\ \text { of feeding } \\ \text { (h) }\end{array} & \begin{array}{c}\text { Washed } \\ \text { fibres }\end{array} & \begin{array}{c}\text { Washings } \\ \text { (excluding } \\ \text { soluble-N) }\end{array} & \text { Soluble-N } \\ 2 & 4 \mathrm{I} & 49 & \text { Percentage of total } \mathrm{N} \text { in } \\ 5 & 37 & 55 & 8 \\ 7 & 43 & 51 & 6 \\ 10 & 40 & 55 & 5 \\ 16 & 36 & 57 & 7 \\ 24 & 28 & 64 & 8\end{array}$

The preliminary separations of nitrogen into washed-fibre- $\mathrm{N}$, washings- $\mathrm{N}$ (excluding soluble-N), and soluble-N made in Exp. 2 are listed in Table 2. The values required to restate these findings in terms of plant and microbial nitrogen are given in Table 3. They include $(a)$ the lignin concentrations in the washed-fibre fractions and in the whole rumen contents - to be used in calculating the amounts of plant nitrogen in the washings fractions, and $(b)$ the DAP-N concentration in the washed-fibre fractions--to be used in calculating the amounts of bacterial nitrogen present in them. 
Table 4 shows the distribution of nitrogen between plant- $\mathrm{N}$, microbial- $\mathrm{N}$ and soluble$\mathrm{N}$ established in this way.

In the samples of rumen protozoa DAP-N was found to contribute less than $0.05 \%$ of the total nitrogen.

Table 3. Exp. 2. Data for correction of crude distribution values given in Table 2

\begin{tabular}{|c|c|c|c|c|c|}
\hline \multirow[b]{2}{*}{$\begin{array}{l}\text { Time after } \\
\text { beginning } \\
\text { of feeding } \\
\text { (h) }\end{array}$} & \multicolumn{3}{|c|}{ Contamination of washings by fine plant particles } & \multicolumn{2}{|c|}{$\begin{array}{c}\text { Contamination of washed } \\
\text { fibres by bacteria as } \\
\text { percentage of total } \mathrm{N} \text { of W.F. }\end{array}$} \\
\hline & $\begin{array}{l}\text { Lignin in W.F. } \\
(\mathrm{g} / \mathrm{1} 00 \mathrm{~g} \text { R.C. })\end{array}$ & $\begin{array}{l}\text { Total lignin } \\
\text { (g/ / } 00 \text { g R.C.) }\end{array}$ & $\begin{array}{c}\text { Percentage } \\
\text { of lignin } \\
\text { present } \\
\text { in washings }\end{array}$ & DAP-N & Bacterial-N* \\
\hline 2 & $1 \cdot 49$ & $\mathrm{I} \cdot 69$ & 12 & 0.26 & 42 \\
\hline$\dot{5}$ & $1 \cdot 46$ & $1 \cdot 61$ & 9 & 0.32 & 52 \\
\hline 7 & $1 \cdot 36$ & I.54 & 12 & 0.36 & $5^{8}$ \\
\hline 10 & $1 \cdot 36$ & 1.45 & 6 & 0.39 & 63 \\
\hline I 6 & $x \cdot 44$ & $I \cdot 7 I$ & 16 & 0.46 & 74 \\
\hline 24 & $\mathbf{1} \cdot 04$ & $x \cdot 24$ & 16 & 0.43 & 69 \\
\hline
\end{tabular}

W.F. $=$ washed fibres $;$ R.C. $=$ rumen contents.

* Assumed $0.62 \%$ DAP-N in the bacterial nitrogen in the sheep of Exp. 2.

Table 4. Exp. 2. Corrected values for percentage distribution of nitrogen in the rumen contents of six sheep

$\begin{array}{cccc}\begin{array}{c}\text { Time after } \\ \text { beginning } \\ \text { of feeding } \\ \text { (h) }\end{array} & \text { Plant-N } & \text { Microbial-N } & \text { Soluble-N } \\ 2 & 27 & 63 & 10 \\ 5 & 20 & 72 & 8 \\ 7 & 20 & 74 & 6 \\ \text { 10 } & \text { I6 } & 79 & 5 \\ \text { I6 } & \text { II } & 82 & 7 \\ 24 & \text { I I } & 8 \text { I } & 8\end{array}$

Table 5. Values required for complete separation of nitrogen in rumen contents of sheep into plant- $N$, bacterial- $N$, protozoal $-N$ and soluble- $N$

(Values for one sheep in Exp. I, slaughtered $24 \mathrm{~h}$ after beginning of feeding)

\begin{tabular}{|c|c|c|c|c|c|c|c|}
\hline Rumen & & & 100 & umen cor & ents & & \\
\hline Concentration & & Washed & & 'Total & & Washings & \\
\hline $\begin{array}{c}\text { bacterial-N } \\
(\%)\end{array}$ & $\begin{array}{l}\text { Total-N } \\
\text { (mg) }\end{array}$ & $\begin{array}{c}\text { DAP-N } \\
(\mathrm{mg})\end{array}$ & $\begin{array}{l}\text { Lignin } \\
\text { (g) }\end{array}$ & $\begin{array}{l}\text { Lignin } \\
\text { (g) }\end{array}$ & $\begin{array}{l}\text { Total-N } \\
\text { (mg) }\end{array}$ & $\begin{array}{c}\text { DAP-N } \\
(\mathrm{mg})\end{array}$ & $\begin{array}{l}\text { Soluble-N } \\
\text { (mg) }\end{array}$ \\
\hline 0.64 & 57.7 & 0.155 & I.06 & I. I9 & 90 & 0.284 & II \\
\hline
\end{tabular}

Table 5 gives a single example of the values required for the complete separation of nitrogen into plant- $\mathrm{N}$, bacterial- $\mathrm{N}$, protozoal- $\mathrm{N}$ and soluble- $\mathrm{N}$. The values are those for one of the sheep in Exp. $I$.

Plant particles present in the 'washings' fraction. If the amount of lignin in the washings is known and also the ratio of lignin to plant- $\mathrm{N}$ has been measured in the 
washed fibres, it is possible to calculate how much plant- $\mathrm{N}$ is present in the washings fraction.

In these experiments the calculated extent of contamination by fine plant particles was always quite small ( $1-4 \%$ of the total nitrogen). It may be that the nitrogen in these fine particles was more extensively removed or digested than in the coarse material of the washed fibres and then the allowances made for this contamination of the microbial fraction would need adjustment. But it is obvious that the corrections could make very little difference in the overall distribution of the nitrogen.

Distribution of nitrogen in the rumen contents. The approximate values given in Table 2 are very similar to those reported earlier (Gray \& Pilgrim, 1953), and it is evident that the washed-fibre fraction contained fairly consistently $30-40 \%$ of the nitrogen, and the washings (excluding soluble-N) about $50-60 \%$. With the aid of the values in Table 3 it is now possible to restate these findings in terms of plant- $\mathrm{N}$ and microbial- $\mathrm{N}$ by allowing for contamination of the washings with plant- $\mathrm{N}$, on the basis of the lignin present, and for contamination of the washed fibres with bacterial-N on the basis of their DAP-N content (Table 4). An example of the method of calculations is as follows:

Sheep slaughtered $7 \mathrm{~h}$ after the beginning of feeding

\begin{tabular}{|c|c|c|c|}
\hline \multicolumn{4}{|c|}{ Distribution of nitrogen in rumen contents } \\
\hline \multicolumn{2}{|c|}{ Washed fibres $=43 \%$} & $\begin{array}{c}\text { Washings (e } \\
\text { soluble-N) }\end{array}$ & Soluble-N $=6 \%$ \\
\hline \multicolumn{2}{|c|}{$\begin{array}{c}\text { DAP-N present in this fraction indicates that } 58 \% \\
\text { of the nitrogen was bacterial-N }\end{array}$} & \multicolumn{2}{|c|}{$\begin{array}{l}\text { Lignin present indicates that } 12 \% \\
\text { of the total plant-N was } \\
\text { included in this fraction }\end{array}$} \\
\hline \multirow[t]{2}{*}{$\begin{array}{l}\text { Bacterial-N } \\
(25 \%)\end{array}$} & $\begin{array}{c}\text { Plant-N } \\
(\text { I } 8 \%)\end{array}$ & $\begin{array}{l}\text { Plant-N } \\
(2 \%)\end{array}$ & $\begin{array}{l}\text { Microbial-N } \\
(49 \%)\end{array}$ \\
\hline & $\begin{aligned} & \text { Distribution: } \text { Plant } \\
& \text { Micr } \\
& \text { Solul }\end{aligned}$ & $\begin{array}{l}20 \% \\
74 \% \\
6.0 \%\end{array}$ & \\
\hline
\end{tabular}

It is evident from a comparison of Tables $I$ and 4 that the distributions finally calculated show a very considerable modification of the crude separations of plant and microbial nitrogen by purely physical methods. The main reason was the very extensive contamination of the washed fibres with bacteria. Probably much contamination could have been removed by further washing, but only at the cost of increasing the contamination of the microbial fraction with fine plant particles. Table 4 shows that the proportion of the nitrogen present in the rumen as plant nitrogen was $\mathrm{I} I-27 \%$ and as microbial nitrogen $63-82 \%$. There appears to have been a steady increase in the proportion of microbial nitrogen at the expense of plant nitrogen as the time after feeding increased. It must be borne in mind that the calculations for Exp. 2 have been based on the assumption that the concentration of DAP-N in the bacterial- $\mathrm{N}$ did not vary widely from the value $0.62 \%$ adopted.

More precise results would have been obtained if the concentrations of the marker had been measured for each animal, but the work was carried out before this need was realized. 
Protozoal nitrogen. Knowledge of the DAP-N content of the 'microbial' fraction will allow its separation into bacterial- $\mathrm{N}$ and protozoal-N, since the protozoa contain no DAP. The values in Table 5 are used as an example to illustrate the calculation, as follows:

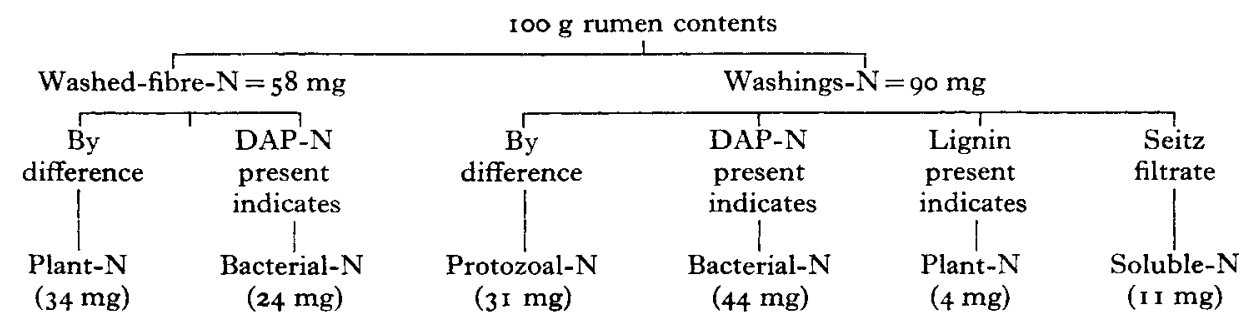

$$
\begin{aligned}
\text { Distribution of nitrogen in rumen contents: Plant-N } \quad(38 \mathrm{mg})=26 \% \\
\text { Bacterial-N }(68 \mathrm{mg})=46 \% \\
\text { Protozoal-N }(3 \text { I mg) }=21 \% \\
\text { Soluble-N } \quad \text { ( I } \mathrm{mg})=7 \%
\end{aligned}
$$

\section{DISCUSSION}

Use of diaminopimelic acid as an indicator of the presence of bacteria. Although it is known that this amino-acid may be absent from some types of bacteria (Work, 1950; Work \& Dewey, I953; Synge, I953) it has been found to be a regular constituent of the very varied and extensive group of bacteria in the rumen. On the other hand, Synge (r953) found that it was absent from hydrolysates of all the usual feeding-stuffs he had examined, and Work \& Dewey (1953), in their survey of I 18 micro-organisms, found the amino-acid to be absent from the two species of protozoa included although present in nearly all of the bacteria. Our own experiments have shown that it is virtually absent from the rumen protozoa of sheep fed on wheaten hay. It would therefore be expected to serve a useful purpose in distinguishing bacterial nitrogen from the other forms of nitrogen in the rumen. This possibility has already been referred to by Synge (1953) who, however, warned that a change in the DAP content of the flora could invalidate any estimate of total microbial protein calculated on this basis. The present investigations have shown that DAP-N accounted for $0.57-0.64 \%$ of the total nitrogen of the mixed rumen bacteria drawn from sheep fed on a ration of wheaten hay. Although some of the largest and smallest organisms were excluded from the bacterial samples analysed, there is little reason to suspect that their inclusion would have seriously altered the composition found for the great bulk of the bacteria present. It seemed possible, however, that the concentration of DAP in the bacteria actually examined might not represent precisely the concentration in the organisms remaining in the washed-fibre fraction. For this reason it was compared with the concentrations of vitamin $B_{12}$ in the bacteria and in the washed fibres. From Table $I$ it can be seen that on the basis of DAP-N content $40-50 \%$ of the nitrogen in the washed fibres was due to the presence of bacteria, whereas on the basis of the vitamin $B_{12}$ content the values were $32-41 \%$. In view of the fact that both $D A P$ and vitamin $B_{12}$ may be absent from some types of bacteria and that the concentration of vitamin $B_{12}$ in bacteria may vary widely from time to time, these values are considered to be in 
sufficiently good agreement to justify considerable confidence in the use of either substance as a quantitative marker of bacterial nitrogen under these circumstances.

Earlier efforts by various investigators to determine the distribution pattern of nitrogen in the rumen have probably all been subject to considerable error because of failure to obtain complete separation by physical methods. Our method does not depend on a complete physical separation of plant material from bacteria, although it does require separation of protozoa from the washed-fibre fraction before the bacterial contamination in the latter is measured. In the application of this procedure to animals fed on any other ration it would be essential to determine the DAP-N concentration in the micro-organisms which develop in the rumen and, further, to check its variation during the feeding cycle. The procedure may prove to be particularly useful for dealing with digesta in which it is obviously impossible to separate the plant fibres from extremely large numbers of adherent bacteria, e.g. digesta derived from pastures and pasture hays.

Extent of conversion of plant nitrogen to microbial nitrogen in the rumen. It has recently been reported (Gray et al. 1958b) that in sheep fed on wheaten hay the amount of nitrogen reaching the abomasum and passing on to the duodenum was equivalent to almost $100 \%$ of the nitrogen eaten-in other words there was no overall loss of nitrogen from the rumen by absorption. Since the present findings indicate that throughout almost the whole day $6 \mathrm{I}-82 \%$ of the nitrogen in the rumen was present as microbial nitrogen, it would seem that this range might also represent the extent of conversion of plant nitrogen to microbial nitrogen. It has been established, however, that the material leaving the rumen consists largely of well-digested food residues even in the period immediately after feeding (Gray et al. I958a). It is therefore possible that the extent of conversion of plant- $\mathrm{N}$ to microbial- $\mathrm{N}$ in the digesta leaving the rumen may have been nearer the upper than the lower limit of the range found in the rumen itself. Examination of the digesta in the omasum would perhaps throw further light on this point.

\section{SUMMARY}

r. The presence of diaminopimelic acid in rumen bacteria and its absence from plants and rumen protozoa have been used as a basis for determining the amounts of bacterial nitrogen present in mixtures of plant nitrogen and microbial nitrogen in rumen contents of sheep.

2. The distribution of nitrogen in rumen contents was determined by first separating the material crudely into plant and microbial fractions by filtration and washing. Correction for the bacteria remaining in the plant-fibre fraction was made on the basis of its diaminopimelic-acid content. Correction for the plant material contaminating the microbial fraction was made on the basis of the amount of lignin present. Soluble nitrogen was determined separately.

3. Examination of rumen material from sheep fed on wheaten hay and slaughtered at intervals ranging from 2 to $24 \mathrm{~h}$ after feeding showed that $63-82 \%$ of the total nitrogen was present as microbial nitrogen, $\mathrm{I}_{\mathrm{I}}-27 \%$ as plant nitrogen, and $5-10 \%$ as soluble nitrogen. 
4. The diaminopimelic acid present in the microbial fraction has also been used to differentiate the bacterial nitrogen from the protozoal nitrogen.

The authors wish to thank Miss M. C. Dawbarn and her colleagues for carrying out assays of vitamin $B_{12}$ activity.

\title{
REFERENCES
}

Dawnbarn, M. C. \& Hine, D. C. (1954). Aust. F. exp. Biol. med. Sci. 32, I.

Gray, F. V. \& Pilgrim, A. F. (1953). Nature, Lond., 172, 347.

Gray, F. V., Pilgrim, A. F. \& Weller, R. A. (1958a). Brit. F. Nutr. 12, 404.

Gray, F. V., Pilgrim, A. F. \& Weller, R. A. (1958b). Brit. F. Nutr. 12, 413.

Hine, D. C. \& Dawbarn, M. C. (1954). Aust. F. exp. Biol. med. Sci. 32, 641.

Moore, S. \& Stein, W. H. (1948). F. biol. Chem. 176, 367.

Moore, S. \& Stein, W. H. (1951). F. biol. Chem. 192, 663.

Synge, R. L. M. (1953). F. gen. Microbiol. 9, 407.

Weller, R. A. (1957). Aust. F. biol. Sci. 1o, 384 .

Work, E. (1950). Biochem. Biophys. Acta, 5, 204.

Work, E. \& Dewey, D. L. (1953). F. gen. Microbiol. 9, 394.

\section{The metabolism of nitrogen, calcium and phosphorus in undernourished children}

\section{4.* The effect of replacing rice in the diet by tapioca macaroni on the metabolism of nitrogen, calcium and phosphorus}

\author{
By KANTHA JOSEPH, M. NARAYANARAO, M. SWAMINATHAN \\ AND V. SUBRAHMANYAN
}

Central Food Technological Research Institute, Mysore, India

(Received 2 May 1958)

In a previous publication from this laboratory, Murthy, Reddy Swaminathan \& Subrahmanyan (I955) reported that undernourished children subsisting on an inadequate and ill-balanced diet grew at subnormal rate but maintained on an average slightly positive nitrogen, calcium and phosphorus balances. In a recent publication, Subrahmanyan, Bhagawan, Doraiswamy, Joseph, Bains, Bhatia, Sankaran \& Swaminathan (1958) found that replacement of rice in the diet of such undernourished children by tapioca macaroni (composed of 60 parts of tapioca flour, 15 parts of lowfat groundnut flour and 25 parts of wheat semolina) for a period of 6 months did not cause any deterioration in the general health, nutritional status and growth of the children. The present paper deals with studies on the effect of replacing rice by tapioca macaroni on the metabolism of $\mathrm{N}, \mathrm{Ca}_{-}$and $P$.

* Paper no. 3: Brit. F. Nutr. (1957), rx, 388. 